原著

\title{
退職後高齢者へのがん検診受診勧奨の重要性 〜山口県がん登録の解析より〜
}

\author{
砂川博史 \\ 山口大学大学院医学系研究科公衆衛生学・予防医学(公衆衛生学) 宇部市南小串 1 丁目 $1-1$ ( $7555-8505)$
}

Key words：がん検診，地域がん登録，医療圈内受診率，定年後退職者，受診钊奨

和文抄 録

【目＼cjkstart的】がん検診の受診に関して，年齢や性別に 加え，高齢化や過疎化といった地域特性も考虑して 現状の分析を行い，がん検診の受診率向上に資する 提言を行うこと.

【対象と方法】山口県がん登録の2008〜2014年のデ 一夕の内, 胃がん, 大腸がん, 肺がんの年齢 $31 \sim 80$ 歳の男女 25,044 例を抽出し, 発見時進展度, 発見経 緯, 医療圈内発見率等について解析を行った.

【結＼cjkstart果】いずれのがんも61歳以上が $80 \%$ 近くを占 めた．発見経緯で検診等を契機に診断された例では 早期が多かった，年齢層が上がるほど検診等の割合 が減る一方, 他疾患観察中の割合が増えていたが, 検診等の患者では，年齢層が上がっても早期割合は 維持できていた．医療圈域内受診率は年齢層が上が るほど高くなっていた.

【考察と結論】高齢者で検診等による発見割合が低 下する要因の一つに定年退職による受診勧奨システ ムの変化が考えられた．がん罹患率が急増する高齢 者にこそ重点的積極的な勧奨が必要で, 効果が期待 されるかかりつけ医からの勧奨に加え, 退職手続き の場や, 地域保健の中での勧奨, 高齢者でも検診発 見例は早期が大多数を占める等の魅力的な事実の提 供等，きめ細かい対策が求められる.

平成31年 1 月 9 日受理
緒言

総務省統計局人口推計によると，平成29（2017） 年10月 1 日現在の我が国の高齢化率は $27.7 \%$, 高齢 者数は3,515万人で, 昭和 25 (1950) 年以降一貫し て上昇が続いており ${ }^{1)}$, 今後もさらに増加が見达ま れ，2042年のピーク時には高齢者数が 3,935 万人に なると推計されている ${ }^{2}$. この高齢化を主な要因と して, 死因のうち, 昭和56（1981）年に男女ともに トップになった悪性新生物は，その後首位を守り続 けている，人口 10 万対の粗死亡率では平成 27 年には 男性359.7, 女性234.6にも達し, 他の疾患による死 亡に比べ増加の割合が高く, 対策は契緊と言える.

平成18（2006）年，がん対策基本法が成立し，基 本施策として, (1)がんの予防及び早期発見の推進 (がんの予防の推進，がん検診の質の向上等)，(2) 几医療の均てん化の促進等（専門的な知識及び技能 を有する医師その他の医療従事者の育成，医療機関 の整備等, がん患者の療養生活の質の維持向上), (3)研究の推進等が挙げられた。 その実行計画として 平成19（2007）年に策定された「がん対策推進基本 計画（第一期）」で，今後のがん対策については, 「がんによる死亡者の減少」及び「すべてのがん患者 及びその家族の苦痛の軽減並びに療養生活の質の維 持向上」を全体目標として,「がん医療」を中心とし つつ,「医療機関の整備等」,「がん医療に関する相談 支援及び情報提供」,「がん登録」,「がんの予防」, 「がんの早期発見」「「がん研究」という分野別施策を 総合的から計画的に実施していくこととなった。 
この内,「がんの早期発見」については，健康増 進法に基づく事業（努力義務）として市町村が行う とされており，その取り組むべき施策として，がん 予防行動の必要性の理解の啓発，未受診者をなくす ことに重点を置いた対策，正確な受診の把握，さら に，がん早期発見手法の改良や開発，検診受診のイ ンセンティブ，受診の利便性の維持確保等が挙げら れている。特に, がん検診の受診率について, 欧米 諸国に比べて低いことも踏まえ, 効果的・効率的な 受診間隔や重点的に受診锥奨すべき対象者を考慮し つつ, 早期発見の重要性が強調されている.

しかしながら，平成28年国民生活基礎調查に基づ くと，がん検診の受診率は，胃がんで男性 $46.4 \%$, 女性 $35.6 \%$ ，大腸がんで男性 $44.5 \%$ ，女性 $38.5 \%$ ，肺 がんで男性51.0\%，女性41.7\%と ${ }^{3)}$ ，平成22（2010） 年以降上昇が続いてはいるものの, 健康日本 $21 て ゙$ 目 標値とされている $50 \%$ に肺がんの男性を除き，届 いておらず，山口県においては，近年がん検診の受 診率は，各検診共に低下傾向にあり，早期発見を是 とする対策面からは憂虑される.

加えて，山口県では平成29（2017）年10月の高齢 化率が全国の $27.7 \%$ に対し $33.5 \%$ と高齢化が進むと共 に，過疎化が進展している。つとに日本創成会議 （座長・増田寛也元総務相）が2014年 5 月，「2040年 に消滅する可能性がある」(消滅可能性都市) と指 摘した全国896市区町村のうち，山口県では，萩市， 長門市，美祢市，周防大島町，上関町，平生町，阿 武町が含まれるなど，深刻な事態となっている．当 該地域の住民には，過疎は日常生活をはじめ，保 健・受療行動上の問題でもある. 即ち過疎地に居住 する高齢者にとって，がん検診を始め，通常の不調 の際にも，比較的人口集積地にある医療機関を受診 することは市街地に住む人々程簡単ではない.

本研究は, がん検診の受診に関して, 年齢や性別 に加え，高齢化や過疎化といった地域特性も考慮し
て現状の分析を行い，がん検診の受診率向上に資す る提言を行うことを目的とする.

\section{対象と方法}

施策目的で当講座が山口県から氏名等の個人情報 を除いた状態で提供を受けていた山口県地域がん登 録システムの持つ2008年から2014年までの登録記録 を，二次利用した．2008～2014年の山口県地域がん 登録システム登録記録数は81,993例で，男性 47,552 例，女性34,441例，年齢は男性 $0 \sim 103$ 歳，女性 0 〜108歳である. 死亡票で初めて登録されたDCN (Death Certificate Notification) は11,535例 (14.1\%), 死亡票で初めて把握され，から，補充調 査を行っても医療機関から届出のないDCO（Death Certificate Only) は5,943例（7.3\%）で，地域がん 登録における量的精度の目標值である DCN $\leqq 25$ 30\%，DCO 15～20\%という基準を満たしている. 原発部位不明（原発部位コードC809）が647例, 進 展度不明（進展度コード499）が8,029例, 該当せず （進展度コード777）は2,313例，発見経緯が空白の まま（発見経緯コードなし）が6,153例，剖検発見 例（発見経緯コード 4）が19例，初期診断医療機関 不定（初診病院医療圈コード 0 ）が1,454例, 同空 白が1,178例である.

この中から，本研究に当たっては，がんの種類を 男女共にがん検診が行われている胃，大腸，肺の 3 つとし，対象年齢は任意のドックや職場健診には 30 歳代も多く受診していることも考慮し，31歳から 80 歳以下とした。患者居住地二次医療圈が不明（診断 時患者居住地医療圈コード 0 ), 初期診断医療機関 の二次医療圈が不定及び空白を除外した，発見時進 展度は，上皮内（進展度コード400），限局（進展度 コード410), 所属リンパ節転移（進展度コード420）, 隣接臟器浸潤（進展度コード430），遠隔転移（進展

表 1 各がん種別男女別抽出症例数

\begin{tabular}{|c|c|c|c|c|c|}
\hline \multicolumn{2}{|c|}{ がんの部位 } & 胃 & 大腸 & 肺 & 総計 \\
\hline \multicolumn{2}{|c|}{$\begin{array}{c}\text { 該当 } \\
\text { ICD } 10 \text { コード }\end{array}$} & $\begin{array}{l}\mathrm{C} 160,161,162,163, \\
164,165,166,168,169\end{array}$ & $\begin{array}{l}\text { C180, 181, 182, 183, 184, } \\
185,186,187,188,189\end{array}$ & $\begin{array}{l}\text { C340, 341, 342, } \\
343,348,349 \\
\end{array}$ & - \\
\hline \multirow{2}{*}{ 性別 } & 男 & 6,059 & 6,116 & 4,673 & 16,848 \\
\hline & 女 & 2,354 & 3,854 & 1,988 & 8,196 \\
\hline \multicolumn{2}{|c|}{ 男女計 } & 8,413 & 9,970 & 6,661 & 25,044 \\
\hline
\end{tabular}

表中に示したICD10コードに該当する患者を各がんの対象者として抽出した．がん種別男女別の数を示す. 
度コード440），不明（進展度コード499）で区分し た. 発見経緯は, がん検診・健康診断・人間ドック での発見例（発見経緯コード 1 ), 他疾患の経過観 察中の偶然発見 (発見経緯コード 3 ), 症状受診を 含む他の経路（発見経緯コード 8 及び 9 ）の 3 つの 群をそれぞれ「検診等」，「他疾患観察中」，「症状受 診」と定義し, 剖検発見（発見経緯コード 4 ）と空 白は除外した。 以上の選択により抽出された 25,044 例を本研究の対象とした（表 1 ).

早期割合の分析に当たっては, 進展度が上皮内お よび限局を早期とした。また，初期診断を受けた医 療機関が患者の居住する二次医療圈域内にある割合
を医療圈内発見率と定義した。統計解析には Microsoft Excel 2016を用いた。

なお，本研究は既に作成されている匿名加工情報 であり，人を対象とする医学系研究に関する倫理指針 における対象に含まれず，倫理審査の適応外である.

\section{結果}

\section{1）がん種別男女別年齢分布（図 1 ）}

図に見る様に，胃がん，大腸がん，肺がんいずれ も，男女とも，加齢とともに増加し，高齢者側に圧 倒的に多く, 61歳以上の割合は胃がんで男性 $82.2 \%$,

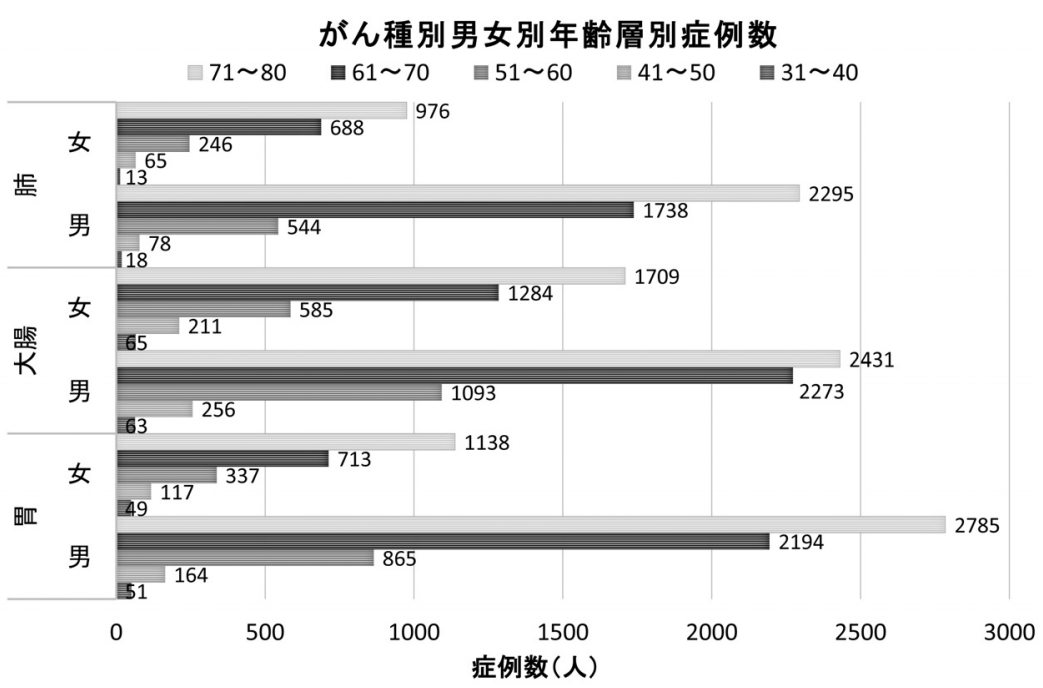

図 1 がん種別男女別年齢層別登録患者数

胃がん, 大腸がん, 肺がんの男女ともに61歳以上の患者数が圧倒的に多い.

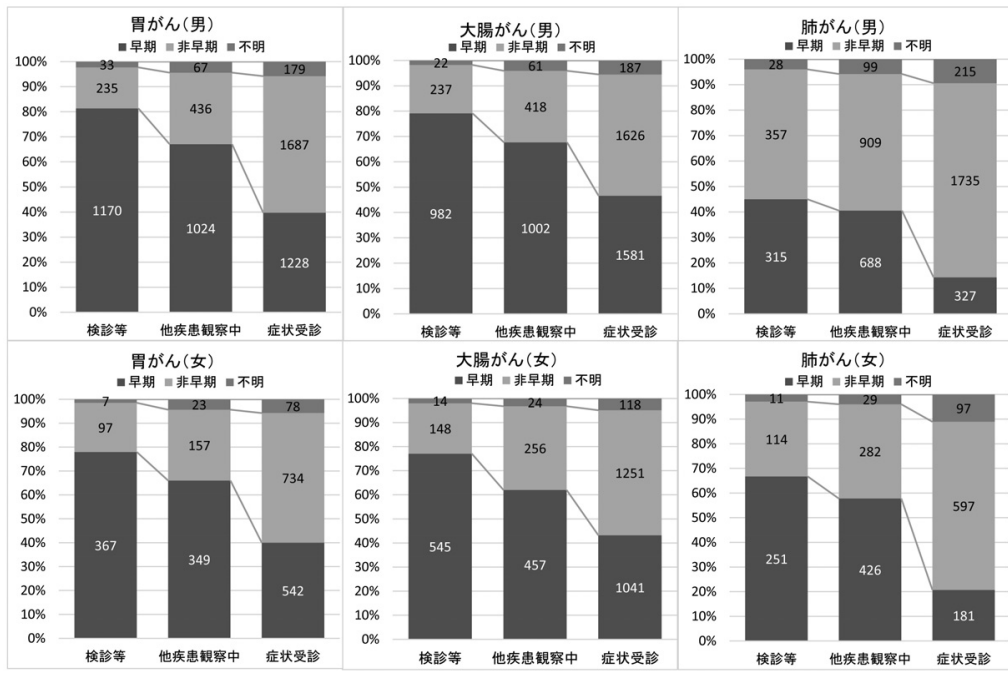

図2 がん種別発見経緯別進展度

症状受診群（各パネルの右の柱）と比べ, 検診等群（同左の柱）での早期割合は明らかに高い. 他疾患観察中はその中間に 位置する。 
女性 $78.6 \%$ ，大腸がんはやや低く男性 $76.9 \%$ ，女性 $77.7 \%$ ，肺がんに至っては，男性 $86.3 \%$ ，女性 83.7\%を占める.

\section{2）がん種別発見経緯別進展度（図 2 )}

検診等での発見であれば，胃がん男性では81.4\%， 女性でも $77.9 \%$ が早期であり, 同様に, 大腸がんで は男性 $79.1 \%$ ，女性 $77.1 \%$ が早期，肺がんでも男性 $45.0 \%$ ，女性 $66.8 \%$ が早期であった。一方，症状受 診での早期割合は，胃がん男性で $39.7 \%$, 女性で $40.0 \%$ ，大腸がん男性で $46.6 \%$ ，女性で $43.2 \%$ ，肺 がん男性で $14.4 \%$, 女性で $20.7 \%$ と，検診等発見の 半分以下である. 他疾患観察中の発見は検診等と症
状受診の中間に位置するが, 肺がんでは検診等に近 い早期割合を示した。 なお，発見経緯別の進展度を 年齢層別に解析したところ，61歳以上の検診等群で は，胃がんと大腸がんにおいては，8割は早期であ り, 同, 症状受診では早期は 4 割以下であった。一 方, 肺がんでは, 早期は検診等群の男性で 4 割強, 女性で 7 割, 症状受診では男性で 2 割に届かず，女 性では 2 割であった。 いずれのがんについても，検 診等で診断された61歳以上の患者の進展度は早期が 多かった。

3）がん種別年齢層別発見経緯（図 3 ）

これら予後に影響を与える発見経緯の割合は，年

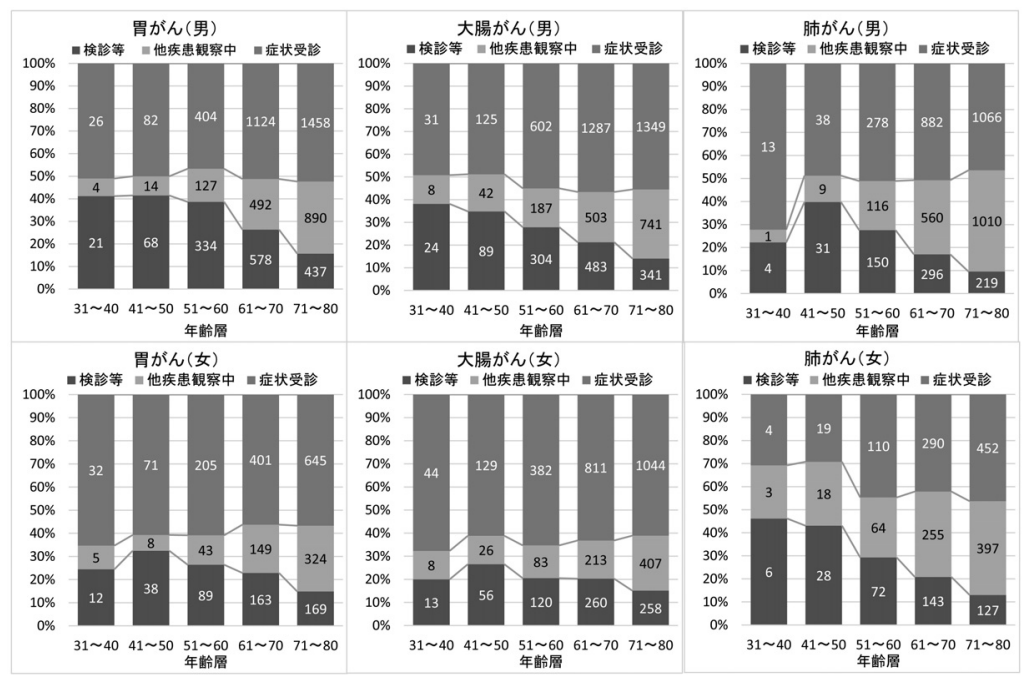

図3 がん種別年齢層別発見経緯割合

何れのがんも, 男女ともに年齢層が上がるほど検診等の割合が減少する. 特に61歳以上での低下が著しい，その一方で, 症 状受診は年齢層による変化は比較的小さく, 寧万他疾患観察中の割合が年齢が上がるにしたがって増えていくのが目立つ.

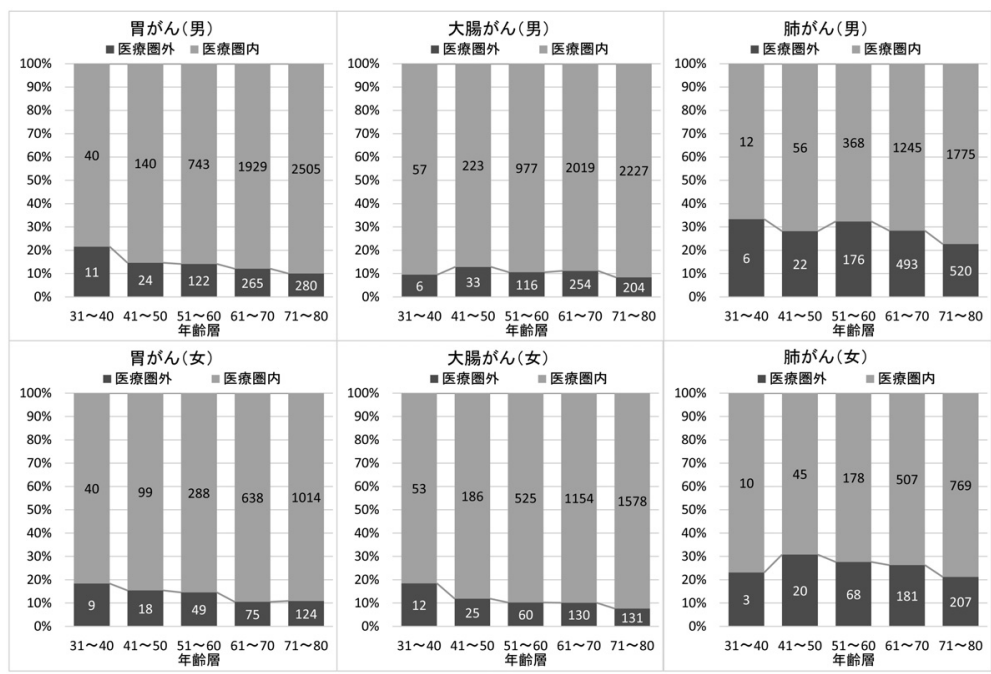

图4 年齢層別医療圈内発見率

どのがんに拀いても年齢層が上がるにつれて医療圈内診断率が高くなる．歳をとるほど身近なところでの診断を受ける傾向 の表れと考えられる。 
齢層に依って変わる. 胃がん, 大腸がん, 肺がんの いずれでも，40歳を過ぎると，男女共に，年齢層が 上がるほど検診等割合が下がり，代わりに他疾患観 察中の割合が増えている. 肺がんでは特にその傾向 が著しい，症状受診の割合はどのがんも，男女とも 殆ど変わらない。

\section{4）がん種別年齢層別医療圏内発見率（図 4)}

先ず，いずれのがんも $7 \sim 8$ 割以上が医療圈内で 発見されているが, 男女ともに, どの年齢層でも肺 がんの医療圈外での発見の割合が，他のがん種と比 べて高いことが目立つ. 大腸がんはやや傾向がそし いが，いずれのがんも，男女共に，年齢層が上がる につれて医療圈内発見率が増えていく.

\section{考察}

\section{1）がんと高齢者}

「がんの統計2017」によると, 胃がん, 大腸がん, 肺がんについては，加齢とともに羅患率が増加する が4), 今回の山口県のがん登録症例でも, 加齢とと もに罹患者数が増加し，圧倒的に高齢者の占める割 合が高かった。このことは，地域の高齢化が進めば 必然的に患者数が増えることを意味する．にもかか わらず，検診等での発見割合は加齢とともに急速に 減っており, 罹患率の高い年齢層に対して検診を勧 奨することは, 検診の効率の面からも重要な視点で ある。

\section{2）発見経緯と進展度}

結果で示したように，がん種によって多少の差は あるものの, 発見経緯が検診等の患者の大多数は早 期である一方，症状受診では早期の割合が検診等の 二分の一から三分の一となって打り, 発見経緯と診 断時の進展度には大きな関連がある。このことは, 検診受診を勧める根拠でもあるし，政策的には検診 受診率の向上を目指す根拠でもある．加齢とともに がん患者は増えるが, 発見経緯別進展度においては, 検診等による発見では，各がんともに高齢層でも早 期が多いことが本研究で明らかになり，年齢に依ら ず検診発見が重要であることが改めて示された.

\section{3）年齢層別発見経緯}

本研究で，年齢層が上がるにしたがって検診等で 発見される割合が低下していることを示したが，こ の傾向は，全国がん登録のデー夕を解析した雑賀ら
の報告 ${ }^{5}$ でも述べられている．年齢が上がると検診 から遠のく背景にはいくつかの要素が考えられる. まず，一つには体力, 他の一つには交通の利便性, これと関連して検診機関の場所との関係があげられ る. 山口県においては特に公共交通機関が衰退して おり,その分マイカーによる移動への依存度が高い。 その一方で, 加齢は, 運転への不安や意欲の減退な どの負の要因となり, この面から検診のためだけに 出かけていくことに抵抗感が増えると考えられる. 但し, 山口県が調查した平成 29 年度「健康づくりに 関する県民調查報告書」には，検診を受けなかった 理由の中で,「受ける場所が不便だから (遠いから)」 は各年代層で多少の差はあるものの3.9〜 7.6\%ほど であったため ${ }^{6)}$, 検診受診のための移動手段だけが 問題であるとは考えにくい. 国民生活調查の中でも, 年齢層別の「がん検診を受けない理由」があげられ ており，60歳未満と60歳以上で区切ってみると, 若 年層の第一位は「受ける時間がない」である一方, 高齢層では「必要な時何時でも受診できる」が最も 多く ${ }^{3}$, これは山口県の平成 29 年度「健康づくりに 関する県民調查」でも同様の結果となっている ${ }^{6}$. 高齢層は多くが定年退職をし, 時間の制約は少なく なる一方, 何らかの慢性疾患でかかりつけ医に通院 しており，「必要なら何時でも受診できる」と考え がちだが，他疾患観察中での発見はがん検診での発 見に比べ早期割合が低く，早期発見の立場から見れ ば，好ましい状況とは言えない。しかしながら，見 方を変えると，彼らはしばしば医師（主治医）と接 しているということである. 26年度版の山口県県民 調查報告書によると「あなたは, どういう状況の時, がん検診を受けようと考えますか」との問いに対し, 「医師，保健師などからすすめられたとき」が $43.4 \%$ と一位であり, 二位の「家族や知人から勧め られたとき」の $25.2 \%$ をきく上回っている7).こ の結果は, 主治医が検診受診を勧めることの効果を 期待させる。つまり, 通院中であるがゆえに, 主治 医の勧奨の機会があり，これを活用することで検診 受診率の向上が期待される。米国CDCの「The Community Guide」には 1 対 1 で専門職が行う教 育の効果が述べられており ${ }^{8)}$, 患者側に「医師や保 健師からの钓めには従いやすい」という現状がある とすれば，期待は一層大きくなる.

また，「定年」の問題を忘れてはいけない。概ね 
60歳代に訪れるこの定年を境に, 多くの人々に大き な生活上, そして健康管理上の変化がもたらされる。 一つには，これまで雇用主の責任で受けさせられて いた検診が任意になる。この結果，検診受診率が低 下し, その反映として検診等発見の割合が下がると 想像され, 本研究の結果でもそれが表れていると思 われる. 今武らの人間ドック受診者対象の大腸がん についての報告でも，60歳代では50歳代に比べて受 診者数が半減し, 70 歳代ではさらに激減している ${ }^{9}$. この変化を医療保険種とある程度結び付ける研究が ある，田淵らは，医療保険種と大腸がん検診受診率 の関連を分析し, 国保加入者の受診率が被用者保険 や共済保険加入者の半分以下であることを指摘した うえで, 市町村国保加入者や被用者保険被扶養者・ 生活保護受給者等を検診受診率が低い，ハイリスク ポピュレーションとまで述べている ${ }^{10}$. この定年に まつわる変化に対応するためには, がんの䍜患率が 高くなる一方, 検診受診を指示する雇用主の存在が 無くなる60歳以上に行政や主治医が積極的な受診勧 奨を行う必要がある。

\section{4）年齢層別医療圏内発見率}

国は都道府県の医療圈ごとのがん対応能力の均て ん化を掲げており，山口県もそれに沿って対策を行 っているが，ほほ 9 割の患者は，居住地が属する医 療圈内の医療機関でがんの診断を受けており, 年齢 層が上がるほど医療圈内医療機関への依存度が高く なることが明らかになった。高齢になり，たとえ車 の運転が難しくなっても受診できるような身近な場 所に検診受診機関があることは重要である.

\section{結語}

山口県地域がん登録データの分析から, 定年退職 を契機とし，加齢と共に検診等での発見率の低下が 起きることが明らかになり，その背景として，検診 勧奨元が雇用者から行政へと替わるシステムの変 化, かかりつけ医のいる人は必要になったらいつで も受けられるという油断, 移動手段の制限などによ る検診受診の困難等が浮かんできた。具体的な検診 受診率向上のための施策として, (1)退職手続きの場 や地域保健の中での退職前後集団への集中的・積極 的钓奨策，(2)かりつけ主治医からの钊奨，(3)がん 検診の理解の促進, すなわち, 高齢でも検診で見つ
かるのは, 壮年期同様, 早期がんが多い事実の周知 などが想起される.

\section{引用文献}

1 ) 総務省. 人口推計. (平成 29 年 10 月 1 日現在) https://www.stat.go.jp/data/jinsui/2017np/pd f/2017np.pdf. (参照2018-12-17)

2 ) 国立社会保障 - 人口問題研究所. 日本の将来推 計人口 (平成29年推計). http://www.ipss.go.jp/ pp-zenkoku/j/zenkoku2017/pp29_gaiyou.pdf. (参照2018-12-17)

3 ）厚生労働省. がん検診の受診状況. 平成28年国 民生活基礎調查の概況.

https://www.mhlw.go.jp/toukei/saikin/hw/ktyosa/k-tyosa16/dl/16.pdf.（参照2018-12-17）

4 ) 公益財団法人 がん研究振興財団. 年齢階級別 がん罹患率推移. がんの統計’ 17. 図表編. 52 . https://ganjoho.jp/data/reg_stat/statistics/br ochure/2017/cancer_statistics_2017_fig_J.pdf. (参照2018-12-17)

5 ）雑賀公美子, 松田智大, 柴田亜希子, 西本 寛, 片野田耕太, 斎藤 博. がん検診等由来や検診 受診率と診断時のがん進行度との関係につい て. JACR. Monograph $2014 ; 20: 11-19$.

6 ) 山口県健康福祉部健康增進課。平成 29 年度 「健康づくりに関する県民意識調查」報告書. 健診（検診）の受診について.

http://www.kenko.pref.yamaguchi.lg.jp/img/ kenko21/download/h29tyousa/H29tyosa_all. pdf. (参照2018-12-17)

7 ) 山口県健康福祉部健康增進課. 平成 26 年度「健 康づくりに関する県民意識調查」報告書. 健診 (検診)の受診について.

http://www.kenko.pref.yamaguchi.lg.jp/img/ kenko21/download/h26tyousa/10-h26jyushin. pdf. (参照2018-12-17)

$8)$ The Community Guide. Systematic Review Cancer Screening : One-on-One Education for Clients -Colorectal Cancer. https://www. thecommunity guide.org/findings/cancerscreening-one-one-education-clients-colorectalcancer. (参照2018-12-19) 
9 ）今武和弘, 小川眞広, 後藤田卓志, 森山光彦. 大腸がん検診における年齢階級別受診動向とが 几発見率の年次推移. 日本がん検診・診断学会 誌 $2017 ; 24: 174-177$.

10）田淵貴大, 中山富雄，西熊秀明。日本における がん検診受診率格差-医療保険のインパクト。 日本医事新報 $2012 ； 4605 ： 84-88$.

Importance of Cancer Screening Checkup Encouragement to Senior Citizens after Retirement $\sim$ Based on Analysis of Yamaguchi Prefecture Cancer Registration 2008-2014

\section{Hiroshi SUNAGAWA}

Public Health and Preventive Medicine (Public Health), Yamaguchi University Graduate School of Medicine, 1-1-1 Minami Kogushi, Ube, Yamaguchi 755-8505, Japan

\section{SUMMARY}

【Purpose】 To analyze the current situation in consideration of the patient's age, gender, regional characteristics such as aging and depopulation, and make recommendations to improve the cancer screening examination rate.

【Target and Method】 From the data of Yamaguchi prefecture cancer registration 20082014, 25,044 people aged 31-80 of stomach, colon, and lung cancer were extracted. We analyzed the interrelationship among the degree of progress, the discovery route, and the discovery rate within the medical area.

【Results】In all cancer nearly $80 \%$ cases were over 61 years. Cancer screening cases were often early. As the age group increased, the proportion discovered during follow-up of other diseases increased, the cancer screening percentage decreased. On the other hand, in cancer screening cases, the early percentage did not change even if the age increased. The medical examination rate within the medical care area increased by age.

【Discussion and Conclusion】 Change in the encourage system occurred at retirement might cause the cancer screening rate declines in elderly people. For elderly people doctor's advice, active recommendation during retirement procedures and in community health, and announcing an attractive fact that over $80 \%$ of cancer screening are early even if you get older are necessary. 